\begin{tabular}{ll}
\hline TOBA Uournal of Tourism, Hospitality and Destination) \\
journal.literasisains.id/index.php/TOBA \\
ISSN Media Elektronik 2828-4100 \\
Vol. 1 No. 1 (Februari 2022) 01-06 \\
DOI: https://doi.org/10.55123/toba.v1i1.75
\end{tabular}

\title{
Pengaruh Service Quality Terhadap Customer Satisfaction Taman Cadika Pramuka Johor Di Medan \\ Furqan $^{1}$, Yogi Putra ${ }^{2}$ \\ Universitas Islam Negeri Sumatera Utara, Jl. IAIN No.1, Gaharu, Kec. Medan Tim., Kota Medan, Sumatera Utara $20235^{1}$ Universitas Battuta, Jl. Sekip No. 1 Simpang Jalan Sikambing, Medani² e-mail: furqanjarkam@gmail.com¹, ogitra@gmail.com²
}

\begin{abstract}
ABSTRAK
Tujuan dari penelitian ini adalah untukk menguji pengaruh kualitas pelayanan terhadap kepuasan pengunjung di Taman Cadika Pramuka Johor Kota Medan. Sampel yang digunakan dalam penelitian ini adalah pengunjung yang mengunjungi Taman Cadika Pramuka Johor Kota Medan.Desain penelitian ini menggunakan penelitian kuantitatif. Sampel yang digunakan dalam penelitian ini adalah para pengunjung yang datang ke Taman Cadika Pramuka Johor Kota Medan Kota Medan sebanyak 100 pengunjung, dipilih berdasarkan teknik pengambilan sampel Non-Probability Sampling dengan teknik Convenience Sampling. Pengumpulan data dalam bentuk kuesioner. Kuesioner likert skala yang digunakan untuk melihat pengaruh Kualitas Pelayanan Terhadap Kepuasan Pengunjung. Sementara data yang dibutuhkan terdiri dari dua variable: Kualitas Pelayanan sebagai variable independen dan Kepuasan Pengunjung sebagai variable dependen. Analisa data yang digunakan dalam penelitian ini adalah terdiri dari analisis regresi linier sederhana dengan SPSS 22.0 dan program computer Microsoft Excel dengan 100 responden Hasil penelitian ini menyimpulkan bahwa variable Kualitas Pelayanan memiliki pengaruh terhadap Kepuasan Pengunjung. Yang dibuktikan dengan skor tingkat Probabilitas Signifikasi adalah Sig. $=0,000$. Dari hasil yang dapat dilihat bahwa signifikasi lebih kecil dari 0,05 (Sig. $<0,05$ ) sedangkan hasil Koefisien pengaruh variable $\mathrm{X}$ terhadap variable $\mathrm{Y}=0.738$ atau $73.8 \%$ yang berarti hasilnya adalah menunjukkan bahwa Kualitas Pelayanan berpengaruh terhadap Kepuasan Pengunjung pada Taman Cadika Pramuka Johor Kota Medan Kota Medan .
\end{abstract}

Kata kunci : Kualitas Pelayanan, Kepuasan Pelanggan, Taman Cadika Pramuka

\section{ABSTRACT}

The purpose of this study was to examine the effect of service quality on visitor satisfaction at Taman Cadika Pramuka Johor Medan City. The sample used in this study were visitors who visited Taman Cadika Pramuka Johor Medan City. This research design uses quantitative research. The sample used in this study were the visitors who came to Taman Cadika Pramuka Johor Medan City Medan City as many as 100 visitors, selected based on the Non-Probability Sampling technique with the Convenience Sampling technique. Collecting data in the form of a questionnaire. Likert scale questionnaire used to see the effect of Service Quality on Visitor Satisfaction. Meanwhile, the data required consists of two variables: Service Quality as the independent variable and Visitor Satisfaction as the dependent variable. The data analysis used in this study consisted of simple linear regression analysis with SPSS 22.0 and Microsoft Excel computer program with 100 respondents. The results of this study conclude that the service quality variable has an influence on visitor satisfaction. As evidenced by the Probability Significance level score is Sig. $=0.000$. From the results, it can be seen that the significance is smaller than 0.05 (Sig. $<0.05$ ) while the results of the coefficient of the influence of the $\mathrm{X}$ variable on the $\mathrm{Y}$ variable $=0.738$ or $73.8 \%$ which means that the results show that Service Quality has an effect on Visitor Satisfaction at Cadika Park. Johor Scouts, Medan City, Medan City.

Keywords : Service Quality, Customer Satisfaction, Scot Cadika Park 


\section{A. PENDAHULUAN}

Kota Medan merupakan salah satu kota terbesar ketiga dengan Jumlah Penduduk : $\mathbf{2 . 4 6 7 . 1 8 3}$ jiwa yang meliputi Luas Wilayah : $265,00 \mathrm{~km}^{2}$, begitu juga kota yang sangat di minati oleh wisatawan dikarenakan memiliki ragam budaya, wisata dll. Dari sekian banyak wisata yang ada di Kota Medan, wisata taman cadika pramuka Johor Kota Medan termasuk salah satu taman yang juga banyak di kunjungi oleh wisatawan. Taman Cadika Pramuka Johor Kota Medan (TWM) sendiri merupakan salah satu tempat wisata yang menawarkan wisata rekreasi keluarga yang sangat bagus dan asri untuk kunjungi, fasilitas utama yang bisa dirasakan salah satu nya arena tempat bermain sepatu roda dan tempat bermain anak - anak.

Pengunjung Taman Cadika Pramuka Johor Kota Medan di lihat dari google reviews yang mengunjungi taman cadika pramuka tersebut sebanyak 4,167 review dengan perolehan binatag 4,4 yang artinya di dalam dunia Industri Pariwisata bahwa taman cadika Pramuka merupakan salah satu taman wisata yang sangat banya di kunjungi wisatawan lokal maupun mancanegara.

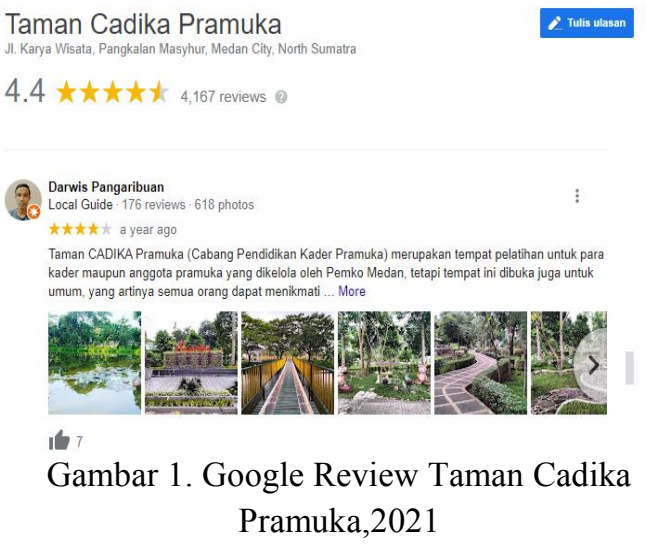

Kotler (2010) kepuasan pelanggan yaitu adalah Keinginan seseorang yang sesuai dengan harapan, sehingga akan memberikan kesan yang positif bagi konsumen setelah merasakan terhadap keinginan yang ingin dia rasakan. Konsumen akan merasakan kepuasan apabila harapan mereka terpenuhi, ketika kepuasan konsumen terwujud akan terciptanya loyalitas konsumen terhadap wisata tersebut

Kualitas Pelayanan pada perusahaan berpengaruh terhadap kepuasan pelanggan, dimana Setiap pelanggan menuntut agar produk atau jasa yang diberikan perusahaan dapat memberi kepuasan yang besar (Kotler \& Amstrong, 2017).

Gambar 1 diatas menunjukkan bahwa Taman Cadika Pramuka Johor Kota Medan sangat banyak diminati wisatawan sehingga meskipun lokasi menuju Taman Cadika Pramuka sering mengalami macet namun taman cadika Pramuka tersebut tetap banyak konsumen yang berkunjung.
Fenomena yang menjadi utama pad ataman rekreasi cadika pramuka Johor Medan yaitu kualitas pelayanan yang masih kurang dirasakan oleh konsumen dimana setiap konsumen yang ingin bertanya atau pun bermain di taman cadika pramuka tersebut petugas agak lambar merespon yang di maksud oleh konsumen, sehingga konsumen enggan untuk bertanya kembali kepada petugas Wisata Taman Cadika Pramuka tersebut.

Penulis tertarik mengambil penelitian di Taman Cadika Johor Kota Medan karena Taman Wisata tersebut sangat asri dan bernuasa dengan alam sehingga sangat pantas dan cocok untuk berlibur membawa anggota keluarga.

Berdasarkan latar belakang masalah tersebut betapa pentingnya kualitas pelayanan agar pengunjung Taman Cadika Pramuka Johor Kota Medan merasa puas dan semakin bertambah disetiap tahunnya. untuk melakukan penelitian mengenai "Pengaruh Servie Quality Terhadap Customer Satisfaction Taman Cadika Pramuka Johor Kota Medan"

\section{B. METODE PENELITIAN}

Menurut zikmund (2009) "metode penelitian survey adalah satu bentuk teknik penelitian dimana informasi dikumpulkan dari sejumlah sampel berupa orang,melalui pertanyaan-pertanyaan",menurut Gay, L. R. dan Diehl, P. L., (1992) "metode penelitian survey merupakan metode yang digunakan sebagai kategori umum penelitian yang menggunakan kuesioner", sedangkan menurut Kenneth D Bailey(2009) "metode penelitian survey merupakan satu metode penelitian yang teknik pengambilan datanya dilakukan melalui pertanyaan tertulis atau lisan".

\section{HASIL DAN PEMBAHASAN \\ Hasil}

\section{Deskripsi Data}

Berdasarkan hasil penelitian yang telah dilakukan, maka hasil penelitian disajikan dalam bentuk penyajian data yang sesuai dengan hasil pengukuran yang dilakukan sebelumnya. Penelitian ini terlaksana dikarenakan dari sampel dijadikan responden untuk diambil data-data. Data yang diperoleh melalui kuesioner, memperlihatkan karakteristik wisatawan/pengunjung Taman Cadika Pramuka Johor Kota Medan. Berdasarkan Jenis Kelamin, Usia, Pendidikan Terakhir, Pekerjaan, dan Pendapatan Perbulan .

Gambar 2

Jenis Kelamin Responden Jenis Kelamin

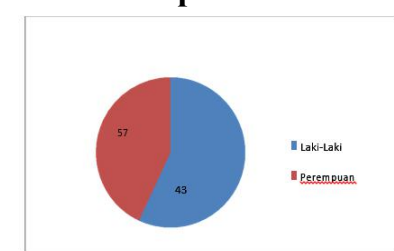




\section{Sumber: Hasil Olah Data, 2021}

Pada diagram diatas menunjukkan bahwa responden laki - laki di Taman Cadika Pramuka Johor Kota Medan dalam penelitian ini sebanyak 43 orang, sedangkan 57 orang repsonden perempuan. Maka kesimpulannya Taman Cadika Pramuka Johor Kota Medan lebih banyak yang mengunjungi perempuan di bandingkan laki - laki.

Gambar 3

Daerah Tempat Tinggal

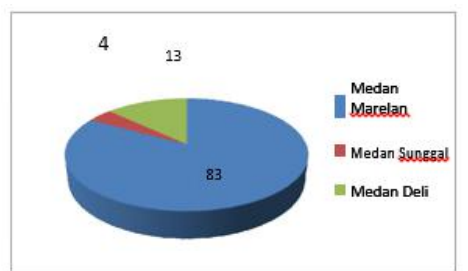

Sumber: Hasil Olah Data, 2021

Dari tabel diatas bisa dilihat pengunjung Taman Cadika Pramuka Johor Kota Medan lebih banyak daerah tempat tinggalnya di Medan Marelan 83 orang, sedangkan Medan Deli hanya 13 orang dan Medan Sunggal 4 orang .

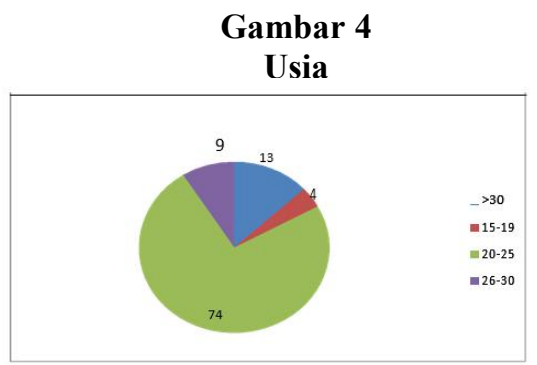

Sumber : Hasil Olah Data, 2021

Dari diagram di atas menunjukan bahwa responden yang mendominasi sebagai pengunjung Taman Cadika Pramuka Johor Kota Medan, responden berusia $20-25$ tahun sebanyak 74 orang, responden berusia $>30$ tahun sebanyak 12 orang, berusia 26-30 tahun sebanyak 9 orang dan berusia 15-19 tahun sebanyak 4 orang. Kesimpulannya bahwa Taman Cadika Pramuka Johor Kota Medan lebih banyak di kunjungi oleh responden dengan usia rentang $20-25$ tahun.

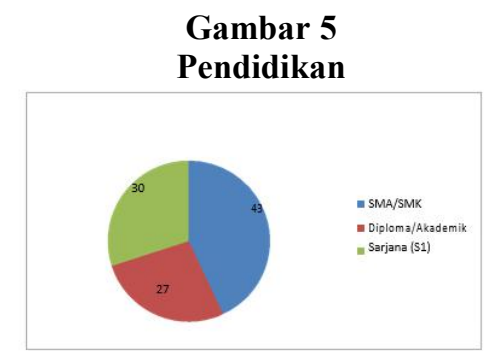

Sumber : Hasil olah data, 2021

Dari diagram diatas menunjukkan Pendidikan terakhir responden yang mengunjungi Taman Cadika Pramuka Johor Kota Medan Kota Medan mempunyai latar belakang pendidikan SMA/SMK 43 orang, diikuti dengan Diploma/Akademi 27, dan S1 (sarjana) 30 orang . Jadi di Taman Cadika Pramuka Johor Kota Medan lebih banyak latar belakang pendidikan terkahirnya SMA/SMK sesuai tabel diatas.

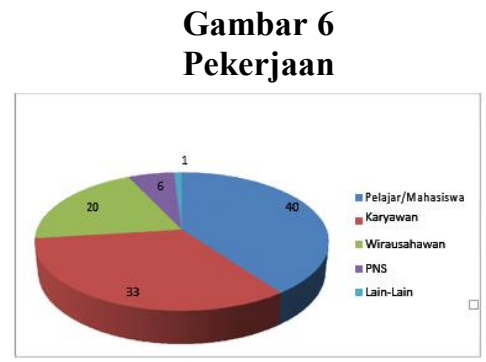

Sumber : Hasil Olah data, 2021

Dari hasil diagram diatas menunjukan bahwa pekerjaan responden yang mengunjungi Taman Cadika Pramuka Johor Kota Medan Kota Medan . Pekerjaan responden dibagi menjadi beberapa kategori, Pelajar/Mahasiswa 40 orang, diikuti dengan karyawan 33 orang, wirausahawan 20 orang, PNS 6 orang dan lain-lain 1 orang. Dari diagram diatas kita bias lihat di Taman Cadika Pramuka Johor Kota Medan lebih banyak pelajar/mahasiswa dibanding pekerjaan yang lainnya .

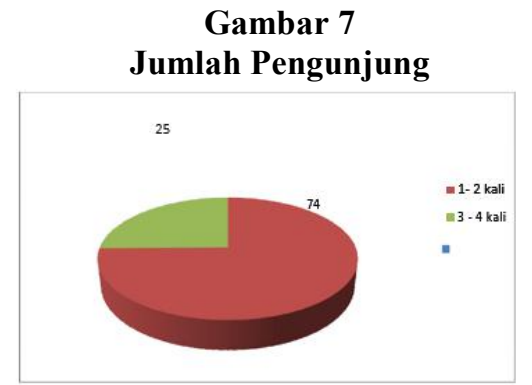

Sumber : Hasil Olahan Data, 2021

Dari data tabel diatas bisa di lihat pengunjung Taman Cadika Pramuka Johor Kota Medan kebanyakan berkunjung dalam satu tahun 1-2 kali 74 orang dan 34 kali 26 orang.

\section{Pembahasan}

\section{Uji Validitas}

Uji validitas adalah uji yang digunakan untuk menunjukan sejauh mana suatu alat ukur yang diakukan dalam suatu penelitian untuk mengukur apa yang ingin diukur. Suatu intrumen dikatakan valid jika informasi yang ada pada tiap item berkolerasi 
erat dengan informasi dari item-tem tersebut sebagai suatu kesatuan, selain itu untuk mengetahui tiap indicator dikatakan valid atau tidak, maka kolerasi tersebut dibandingkan dengan 0,5 dimana jika nilai kolerasi (r) lebih dari 0,5, maka instrumen tersebut dinyatakan valid, begitu pula sebaliknya.

Sebagai mana yang dinyatakan masrun yang dikutip oleh sugiono (2014:178): “item yang mempunyai koreksi positif dengan kriterium (skor total) serta korelasi yang tinggi menunjukkan bahwa item tersebut mempunyai validitas yang tinggi .

Maka dalam penelitian ini dikatakan data yang diperoleh valid jika :

$\sum$ Data pada tabel corrected item total correlation $<0.3$ maka belum bisa valid

$\sum$ Data pada tabel corrected item total correlation $>0.3$ maka dapat dikatakan data yang diperoleh valid

Tabel 1

Uji Validitas Variabel Kualitas Pelayanan Correlations

Rata-Rata $x$

\begin{tabular}{|l|c|c|c|}
\hline & $\begin{array}{c}\text { Pearson } \\
\text { Correlation }\end{array}$ & $\begin{array}{c}\text { Significance } \\
\text { (2-tailed) }\end{array}$ & N \\
\hline Bukti Fisik 1 & $.765^{* *}$ & .000 & 100 \\
Bulti Fisik 2 & $.787^{* *}$ & .000 & 100 \\
Kehandalan 1 & $.765^{* *}$ & .000 & 100 \\
Kehandalan 2 & $.867^{* *}$ & .000 & 100 \\
Daya Tanggap 1 & $.854^{* *}$ & .000 & 100 \\
Daya Tanggap 2 & $.830^{* *}$ & .000 & 100 \\
Jaminan 1 & $.854^{* *}$ & .000 & 100 \\
Jaminan 2 & $.656^{* *}$ & .000 & 100 \\
Empati 1 & $.871^{* *}$ & .000 & 100 \\
Empati 2 & $.866^{* *}$ & .000 & 100 \\
Rata-Rata x & 1 & & 100 \\
Total x & $1.000^{* *}$ & .000 & 100 \\
\hline
\end{tabular}

Sumber : Hasil olah data SPSS, 2021

Berdasarkan Tabel diatas maka dapat dilihat bahwa seluruh pertanyaan untuk variabel kualitas pelayanan memiliki Status Valid, karena nilai correlation $>$ tabel sebesar 0.500 .

Tabel 2

Uji Validitas pada Variabel Kepuasan Pengunjung Correlations Rata-Rata y

\begin{tabular}{|l|c|c|c|}
\hline & $\begin{array}{c}\text { Pearson } \\
\text { Correlation }\end{array}$ & $\begin{array}{c}\text { Significance( } \\
\text { 2-tailed) }\end{array}$ & N \\
\hline Kualitas produk 1 & $.785^{* *}$ & .000 & 100 \\
Kualitas produk 2 & $.876^{* *}$ & .000 & 100 \\
Harga 1 & $.764^{* *}$ & .000 & 100 \\
Emosiona1 1 & $.851^{* *}$ & .000 & 100 \\
Emosiona1 2 & $.723^{* *}$ & .000 & 100 \\
Biaya 1 & $.670^{* *}$ & .000 & 100 \\
Rata-Rata y & 1 & & 100 \\
Total y & $1.000^{* *}$ & .000 & 100 \\
\hline
\end{tabular}

Sumber :Sumber : Olah data SPSS, 2021

Berdasarkan tabel diatas maka dapat dilihat bahwa seluruh pertanyaan untuk variabel kepuasan pengunjung memilik status valid.

\section{Uji Reliabilitas}

Uji reliabilitas menunjukan pada suatu pengertian bahwa instrument yang digunakan dalam peneliti untuk memperoleh informasi yang diinginkan dapat percaya sebagai alat pengumpulan data serta mampu mengungkap informasi yang sebenarnya dilapangan. Maka dalam penelitian ini dikatakan data yang di peroleh reliabilitas jika :

$\sum$ Data pada tabel Cronbach alpha $<0.6$, maka data tersebut belum bias di katakana reliabel

$\sum$ Data pada tabel Cronbach alpha $>0.6$, maka data tersebut sudah bias dikatakan reliabel.

Tabel 3

Hasil Uji Reliabilitas (X) Reliability Statistics

\begin{tabular}{|c|c|}
\hline Cronbachs Alpha & N of Item s \\
\hline .854 & 10 \\
\hline
\end{tabular}

Sumber : Hasil Olah Data SPSS, 2021

Hasil dari tabel diatas didapatkan nilai koefisien Cronbach Alpha lebih dari 0.6 yang dinyatakan bahwa semua butir pertanyaan reliabel .

Tabel 4

\section{Hasil Uji Reliabilitas (Y) Reliability Statistics}

\begin{tabular}{|l|l|}
\hline Cronbachs Alpha & N of Items \\
\hline 751 & 6 \\
\hline
\end{tabular}

Sumber : Hasil Olah Data SPSS, 2021

Hasil dari tabel diatas didapatkan nilai koefisien Cronbach Alpha lebih dari 0.6 yang dinyatakan bahwa semua butir pertanyaan reliabel.

\section{Uji Normalitas}

Uji Normalitas adalah sebuah uji yang dilakukan dengan tujuan untuk menilai sebaran data pada sebuah kelompok data atau variabel, apakah sebaran data tersebut berdistribusi normal ataukah tidak. Pengujian ini menggunakan uji Kolmogrov-Smirnov, 
dengan syarat berikut : $\sum$ Jika nilai signifikan $<0.05$ maka distribusi data tidak normal $\sum$ Jika nilai signifikan $>0.05$ maka, distribusi data normal.

Tabel 5

One-Sample Kolmogorov-Smirnov Test

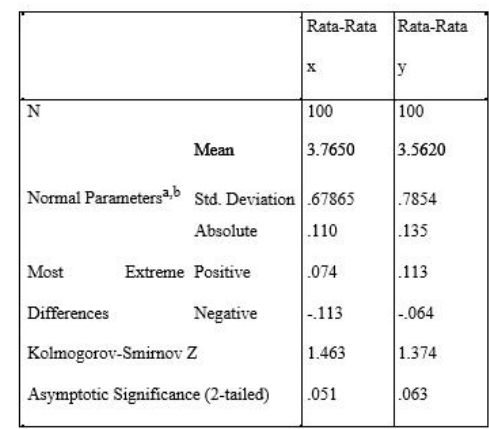

Sumber : Hasil Olah Data SPSS, 2021

Dari hasil olah data SPSS tampak bahwa nilai signifikan menunjukan bahwa nilai residual telah terdistribusi secara normal .

\section{Gambar 6}

Garis P-p Plot Normalitas

(dependen Variabel : Kepuasan Pengunjung)

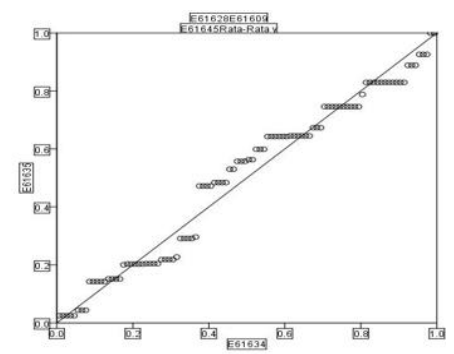

Sumber : Hasil Olah Data SPSS, 2021

\section{Uji Koefisiensi Korelasi dan Koefisien Determinasi}

Uji ini merupakan salah satu statistic infarensi yang akan menguji apakah dua variabel atau lebih yang mempunyai hubungan atau tidak.

\section{Tabel 6}

Koefisien Korelasi dan Koefisien Determinasi Model Summary ${ }^{b}$

\begin{tabular}{|l|l|l|l|l|}
\hline Model & R & R Square & $\begin{array}{l}\text { Adjusted } \\
\text { Square }\end{array}$ & $\begin{array}{l}\text { Std. Error of } \\
\text { the Estimate }\end{array}$ \\
\hline 1 & $.831^{\mathrm{a}}$ & .724 & .675 & .4364 \\
\hline
\end{tabular}

\section{Sumber : Hasil Olah Data SPSS, 2021}

Pada table 6 di atas menunjukkan bahwa nilai Koefisien Korelasi dalam penelitian ini sebesar 0.831 . nilai korelasi tersebut menggambarkan bahwa hubungan variabel independen (x) yaitu Kualitas pelayanan dengan variabel dependen (y) kepuasan pengunjung memiliki hubungan yang sangat kuat

Sedangkan nilai Koefisien Determinasi atau R adalah 0.724 atau $72.4 \%$ sedangkan sisanya sebesar $27.6 \%$ dipengaruhi oleh variabel lain yang tidak termasuk dalam penelitian.

\section{Uji F}

Uji F dikenal dengan uji serentak atau Uji Anova yaitu uji

Tabel 7

ANOVAa

\begin{tabular}{|ll|l|l|l|l|l|}
\hline Model & & Sum of Squares & df & Mean Square & F & Significance \\
\hline & Regression & 36.573 & 1 & 36.573 & 320.123 & $.000^{\mathrm{b}}$ \\
\hline 1 & Residual & 15.426 & 87 & .098 & & \\
\hline & Total & 54.640 & 90 & & & \\
\hline
\end{tabular}

a. Dependent Variable: Rata-Rata y

b. Predictors: (constant) Rata-Rata X..

Melihat bagaimanakah pengaruh semua variabel bebasnya secara bersama-sama terhadap variabel terikatnya, atau untuk menguji apakah model regresi yang dibuat baik/signifikan atau tidak baik/nonsignifikan.

\section{Modeling Regresi Linear Sederhana}

Regresi linear sederhana, yaitu regresi linier yang hanya melibatkan 2 variabel (variabel $\mathrm{x}$ dan $\mathrm{y}$ ). Persamaan regresi linier dari $\mathrm{X}$ terhadap $\mathrm{Y}$ dirumuskan dimana:

$$
\mathbf{Y}=\mathbf{a}+\mathbf{b X}
$$

$\mathrm{Y}=$ Variabel terikat

$\mathrm{X}=$ Variabel bebas

$\mathrm{a}=$ Intersep

$\mathrm{b}=$ Koefisien regresi/slop

Keterangan:

$\mathrm{Y}=0.206+0,880 \mathrm{X}$

Penjelasan dari persamaan tersebut adalah sebagai berikut:

a. Nilai konstanta (a) adalah 0.206, menunjukkan bahwa Kualitas Pelayanan bernilai positif, yaitu 0.206 yang dapat mempengaruhi Kepuasan Pengunjung.

b. Nilai koefisien regresi variabel Kualitas Pelayanan sebesar 0,880, menunjukkan bahwa terdapat pengaruh positif variabel bebas Kualitas Pelayanan (x) terhadap variabel Kepuasan Pengunjung (y). Angka koefisien 
regresi tersebut juga menunjukkan bahwa setiap ada kanaikan satu nilai Kualitas Pelayanan maka akan terdapat kenaikan pada Kepuasan Pengunjung sebesar 0.880.

c. Untuk membuktikan hipotesa penelitian ini, dapat dijelaskan bahwa variabel Bauran Pemasaran mempunyai nilai signifikansi sebesar 0,000, sehingga dapat dikatakan bahwa H0 ditolak. Dengan demikian dapat disimpulkan bahwa Kualitas Pelayanan berpengaruh terhadap Kepuasan Pengunjung, artinya Kualitas Pelayanan berpengaruh positif terhadap Kepuasan Pengunjung Taman Cadika Pramuka Johor Kota Medan.

\section{E. SIMPULAN}

Meningkatkan minat masyarakat untuk berwisata, hal ini dilakukan sebagai penghilang penat setelah melakukan berbagai rutinitas yang dilalui setiap harinya. Pariwisata memang memiliki daya ikat tersendiri, dengan menawarkan berbagai macam kategori wisata seperti wisata alam, wisata budaya, wisata edukasi, wisata kuliner dan lain-lain. Kategori wisata ini pun mampu menarik wisatawan domestic maupun mancanegara.

\section{DAFTAR PUSTAKA}

Goestsh dan davis. 2013. Quality Management, Fourth edition. Cram101 Incorporated

Kotler, Philip and Gary Armstrong. 2012. PrinsipPrinsip Pemasaran. Edisi 13. Jilid 1 . jakarta: Erlangga

Ridwan,Mohamad. (2012), Perencanaan dan Pengembangan Pariwisata. PT SOFMEDIA: Medan.

Septi Winarsih, Atik \& Ratminto. 2012. Manajemen Pelayanan. Yogyakarta :Pustaka Pelajar

Sugiyono. 2012. Metode Penelitian Kuantitatif Kualitatif dan R\&D. Bandung : Alfabeta

Tjiptono, Fandy dan gregorius Chandra, 2012, Pemasaran Strategik. Yogyakarta, ANDI

Tjiptono, Fandy dan Gregorius Chandra, Pemasaran Strategik. Yogyakarta, ANDI, 2012 